\title{
Antioxidant Action of Rosemary and Oregano Extract in Pre-Cooked Meet Hamburger
}

\author{
Maria Raquel Manhani1, Maria Aparecida Nicoletti ${ }^{*}$, Andrea Carla Da Silva Barretto ${ }^{3}$, \\ Graciele Riveres De Jesus ${ }^{4,5}$, Camila Munhoz ${ }^{5,6}$, Gabriel Ramos De Abreu ${ }^{5}$, \\ Julia Zaccarelli-Magalhães, ${ }^{5}$ André Rinaldi Fukushima ${ }^{4}$ \\ ${ }^{1}$ Instituto Federal de São Paulo (IFSP), Campus Suzano, Suzano, Brazil \\ ${ }^{2}$ Faculty of Pharmaceutical Sciences, University of São Paulo, São Paulo, Brazil \\ ${ }^{3}$ Instituto de Biociências Letras e Ciências Exatas de São José do Rio Preto, Universidade Estadual Paulista Júlio de Mesquita Filho, \\ São José do Rio Preto, Brazil \\ ${ }^{4}$ Universidade São Judas Tadeu, São Paulo, Brasil \\ ${ }^{5}$ Department of Pathology, School of Veterinary Medicine and Animal Science, University of São Paulo, São Paulo, Brazil \\ ${ }^{6}$ Health Science Institute, Presbiterian Mackenzie University, São Paulo, Brazil \\ Email: rmanhani@yahoo.com.br, *nicoletti@usp.br, fukushima@usp.br
}

How to cite this paper: Manhani, M.R. Nicoletti, M.A., Da Silva Barretto, A.C., De Jesus, G.R., Munhoz, C., De Abreu, G.R., Zaccarelli-Magalhães, J. and Fukushima, A.R. (2018) Antioxidant Action of Rosemary and Oregano Extract in Pre-Cooked Meet Hamburger. Food and Nutrition Sciences, 9, 806-817.

https://doi.org/10.4236/fns.2018.97060

Received: June 5, 2018

Accepted: July 15, 2018

Published: July 18, 2018

Copyright $\odot 2018$ by authors and Scientific Research Publishing Inc. This work is licensed under the Creative Commons Attribution International License (CC BY 4.0).

http://creativecommons.org/licenses/by/4.0/

\begin{abstract}
The main goal is to compare the antioxidant potential of rosemary and oregano natural extracts in precooked beef burger by assessing the lipid oxidation extent and sensory analysis. Five formulations (F) of hamburger were prepared from beef and mechanically separated as follows: meat containing sodium erythorbate (F1); deodorized rosemary extract (F2); oregano extract (F3); rosemary plus oregano extracts (F4) and without antioxidant addition, denominated control formulation $(\mathrm{CF})$. The samples were frozen at $-18^{\circ} \mathrm{C}$ for 24 hours, then submitted to heat treatment in an electric oven with internal controlled temperature of $75^{\circ} \mathrm{C}$, and again frozen for a period of 30 days. The lipid oxidation extent (determined by thiobarbituric acid reactive substancesTBRS) was evaluated at 0,15 during 30 days. After heating in plate to temperature of $75^{\circ} \mathrm{C}$, the samples were submitted to color, taste and odor evaluation by 40 untrained tasters. The formulations F1, F2 and F4 presented lower concentrations of TBRS, whereas CF at day zero already showed very high values, indicating oxidation of the product. The samples showed good acceptance in the sensorial analysis.
\end{abstract}

\section{Keywords}

Rosemary Extract, Oregano Extract, Food Composition, Food Preservation, 
Food Quality, Meat Product

\section{Introduction}

One of the main factors that affect meats and meat products quality is the occurrence of lipid oxidation, compromising significantly consumer acceptance. This process leads not only to discoloration and nutritional value loss, but also to food rejection due to rancid flavors caused by the oxidized products. Food rancidity does not only affect products sensory, but is also responsible for the emergence of toxic compounds associated with health problems, such as circulatory diseases, cancer and aging [1] [2].

For this to be avoided, synthetic substances such as butyl hydroxytoluene (BHT) and butyl hydroxyanisole (BHA) are added to retard or prevent oxidation in foods containing fat, but they have commercial limitations, since they contain a certain toxicity and phenolic odor. Currently, there is a wide variety of natural antioxidants employed in various industrialized foods and much attention has been given to those derived from herbs and spices. Food industry has an increasing interest for natural substances that can replace the synthetic ones in order to produce healthier foods that meet the demands of the consuming public [3] [4].

In this sense, spices like rosemary and oregano, widely used in cooking, were promising in studies conducted with rosemary (Rosmarinus officianalis L.) and oregano (Oreganum vulgare L.). These leaves showed inhibition of oxidative degradation in fatty foods with the possibility of industrial application [5] [6].

In research carried out with vacuum-packed, roasted and vacuum-packed meat containing $0.1 \%$ water-soluble deodorized rosemary extract, the product presented low levels of lipid oxidation during sixty days of storage at $-18^{\circ} \mathrm{C}$ [7].

The rosemary extract obtained by the supercritical extraction technique with $\mathrm{CO}_{2}$-SFE showed excellent performance when used in several foods, cosmetics and pharmaceuticals, in which natural aroma, color and antioxidant and/or antimicrobial activity were desired [8].

These properties are very relevant to food industry concerning the search for possible substitutes to food synthetic preservatives. However, further studies must be done to investigate the behavior of natural extracts in food, considering all quality requirements requested by the food system.

Oxidative rancidity begins as soon as the animal dies, when blood flow stops and metabolic processes are disrupted. The steps comprising such deterioration process are formed by many chemical reactions, resulting many complex products. Unsaturated lipids provide the substrate for the reaction to occur and catalysis happens through the action of oxygen, light, heavy metals and others, being one of the major causes of meat products deterioration [9].

Particularly, in the case of cooked meat, the taste deterioration is one of the 
most important revealed changes. During peroxidation, polyunsaturated fatty acids are degraded into short chain volatile components, such as aldehydes, ketones, alcohols, esters and acids, compromising both, odor and taste. This phenomenon increases during subsequent cooking and storage. It is recognized as popularly called "reheated" flavor or WOF-Warmed-Over Flavor, which is a major concern for precooked meats. The development of unpleasant flavors and odors greatly reduces consumer acceptability [7].

In phytochemistry, there is a huge interest for searching new natural sources of antioxidants and antimicrobial agents, which demands debating on the safe aspects of chemical preservatives, since these are considered carcinogenic and teratogenic, in addition to originating toxic residues [10] [11].

The rosemary (Rosmarinus officinalis L.) is a medicinal plant widely used around the world and one of the species with the highest antioxidant activity [12]. Many compounds have been extracted from rosemary, including flavonoids, diterpenes, steroids and triterpenes. Among these compounds, rosemary antioxidant activity has been attributed to two phenolic diterpenes, mainly: carnosine acid and carnosol [13] [14].

Five antioxidative phenolic acids were isolated from the oregano leaves (Origanum vulgare L.). The structure of a new compound (5a) was determined to be 2-caffeoyloxy-3-[2-(4-hydroxybenzyl)-4,5-dihydroxy]phenylpropionic acid on the basis of spectroscopic evidence. Especially, phenyl glucoside (1) and 5a showed an activity comparable to BHA [6] [15].

Vekiari and co-workers [16] studied the fractionation of oregano extract with various solvents (petroleum ether, ethyl ether, ethyl acetate and butanol) and results showed that the fraction diluted in ethyl ether was the most effective in protection against animal fat lipid oxidation when stored under light and at $65^{\circ} \mathrm{C}$, equivalent to the action of butyl-hydroxy toluene. This same extract had also a good performance as an antioxidant in refined vegetable oils when stored at $35^{\circ} \mathrm{C}$ and $65^{\circ} \mathrm{C}$ and then subjected to frying.

Antimicrobial activities of six essential oils commonly used as condiments in Brazil (Ocimum basilicum L. (basil), Rosmarinus officinalis L. (rosemary), Origanum majorana L. (marjoram), Mentha piperita L. var. Piperita (peppermint), Thymus vulgaris L. (thyme) and Pimpinella anisum L. (anise) against Clostridium perfringens. The results obtained in this study demonstrated that the essential oils of basil, rosemary, marjoram, peppermint, thyme and anise exhibit, in vitro, antimicrobial activities against $C$. perfringens. The use of essential oils from commonly employed spices clearly offers an alternative to the chemical preservatives in the control and inactivation of pathogens in food, but further studies are needed in order to verify direct application in commercially produced food systems. The results suggest that the oxygenated compound, especially oxygenated monoterpenes and phenylpropanoids, might be responsible for the antimicrobial activity against $C$. perfringens [17].

In study carried out by Trindade [5], the sensorial analysis showed that 
among beef hamburger samples formulated with natural antioxidants, i.e., 400 $\mathrm{mg} / \mathrm{kg}$ oregano extract and $400 \mathrm{mg} / \mathrm{kg}$ rosemary extract, irradiated and frozen for 90 days, those containing oregano received the highest marks among the tasters.

Therefore, the study of the vegetal origin extracts incorporated as antioxidants in foods aims to expand possibilities for other viable alternatives that ensure the integrity of the industrialized products.

Considering the literature findings, the objective of this study is to evaluate rosemary and oregano antioxidant potential in precooked beef burger stored under freezing and to determine the extent of lipid oxidation through physical-chemical and sensory analysis evaluations.

\section{Materials and Methods}

\subsection{Materials}

\subsubsection{Raw Material and Additives}

For the hamburgers preparation were used the following raw materials and additives: Chuck Beef (Meat), Mechanically Separated Meat (MSM), Bacon, Deodorized Oregano Extract-DANISCO S.A., Deodorized Rosemary ExtractDANISCO S.A., Iodized Salt refined-Sal Cisne/Refinaria Nacional de Sal, sodium erythorbate-SUNTRAN S.A.

Both extracts were commercially acquired (DANISCO S.A.)

\subsubsection{Hamburgers Formulation, Production and Storage [18]}

Sample treatment: Forty samples of five hamburger formulations-100 g each (F1, F2, F3, F4 and Control Formulation-CF) were prepared, totalizing two hundred samples, containing 70\% chuck, $10 \%$ MSM, 10\% bacon, $8 \%$ ice water, $2 \%$ iodized salt and different concentrations of antioxidants according to Table 1 and Table 2.

The samples were frozen at $-18^{\circ} \mathrm{C}$ for 24 hours, and then subjected to heat treatment in an electric oven with internal controlled temperature of $75^{\circ} \mathrm{C}$. After heat treatment, the samples were packed in plastic film, and frozen at $-18^{\circ} \mathrm{C}$ for

Table 1. Hamburger formulations.

\begin{tabular}{cccccc}
\hline Raw material and additives & CF & F1 & F2 & F3 & F4 \\
\hline Ground chuck beef & $4.25 \mathrm{~kg}$ & $4.25 \mathrm{~kg}$ & $4.25 \mathrm{~kg}$ & $4.25 \mathrm{~kg}$ & $4.25 \mathrm{~kg}$ \\
MSM & $0.50 \mathrm{~kg}$ & $0.50 \mathrm{~kg}$ & $0.50 \mathrm{~kg}$ & $0.50 \mathrm{~kg}$ & $0.50 \mathrm{~kg}$ \\
Ice water & $0.40 \mathrm{~kg}$ & $0.40 \mathrm{~kg}$ & $0.40 \mathrm{~kg}$ & $0.40 \mathrm{~kg}$ & $0.40 \mathrm{~kg}$ \\
Bacon & $0.25 \mathrm{~kg}$ & $0.25 \mathrm{~kg}$ & $0.25 \mathrm{~kg}$ & $0.25 \mathrm{~kg}$ & $0.25 \mathrm{~kg}$ \\
Sodium chloride & $0.10 \mathrm{~kg}$ & $0.10 \mathrm{~kg}$ & $0.10 \mathrm{~kg}$ & $0.10 \mathrm{~kg}$ & $0.10 \mathrm{~kg}$ \\
Sodium erythorbate & - & $0.0025 \mathrm{~kg}$ & - & - & - \\
Rosemary extract & - & - & $0.005 \mathrm{~kg}$ & - & $0.005 \mathrm{~kg}$ \\
Oregano extract & - & - & - & $0.005 \mathrm{~kg}$ & $0.005 \mathrm{~kg}$ \\
\hline
\end{tabular}


Table 2. Antioxidants concentration in the different hamburger formulations.

\begin{tabular}{cccc}
\hline Formulations & Rosemary extract $\mathbf{m g} / \mathbf{k g}$ & Oregano extract $\mathbf{m g} / \mathrm{kg}$ & Sodium erythorbate $\mathrm{mg} / \mathrm{kg}$ \\
\hline CF & 0 & 0 & 0 \\
F1 & 0 & 0 & $500^{*}$ \\
F2 & 1000 & 0 & 0 \\
F3 & 0 & 1000 & 0 \\
F4 & 1000 & 1000 & 0 \\
\hline
\end{tabular}

${ }^{*}$ Concentration limit recommended by legislation [19].

a period of 30 days.

\subsection{Methods}

\subsubsection{Determination of Lipids [20]}

Food lipids determination is carried out by solvent extraction and, in general, ethyl ether or petroleum ether, which are heated in an intermittent extractor (Soxhlet apparatus). The resulting ethereal extract includes, mainly, the oil/fat resultant, although it also encompasses other soluble substances.

\subsubsection{Evaluation of Lipid Oxidation [21]}

Samples lipid oxidation was determined to triplicate at 0,15 in 30 days, using a methodology recommended by Tarladgis and co-workers [21], in which thiobarbituric acid reactive substances are measured. The samples were crushed, water was added, and then subjected to distillation. Distillate aliquots were added thiobarbituric acid solution, generating colored complexes, whose intensity was measured in a spectrophotometer and subjected to the absorbance reading (A) at a wavelength of 532 nanometers. Primary lipid oxidation products are mainly hydroperoxides, which are rapidly decomposed into various thiobarbituric acid (TBA) reactive substances, particularly carbonyls; malonaldehyde is considered the most important compound.

\subsubsection{Physicochemical Characterization}

Moisture and ashes content determinations were conducted according to the technique described in Institute Adolfo Lutz [20].

\subsubsection{Sensory Analysis}

"Antioxidant action of rosemary and oregano extracts on pre-cooked beef burger" Project was submitted to the Research Ethics Committee of the University of São Judas Tadeu (USJT) and was approved in a consubstantiated opinion number 063/2009.

\section{1) Tasters Selection}

Tasters were invited to attend the Gastronomy and Dietary Technique Laboratory of the University of São Judas Tadeu-USJT for conducting the sensory acceptance tests through posters posted on USJT murals and e-mail notifications to the USJT internal community. The posters and warnings specified the type of 
test and the product to be evaluated.

\section{2) Tasters inclusion and exclusion criteria}

Prior to the tests, tasters were asked to complete a questionnaire and to sign the Free and Informed Consent Form. Were selected only the tasters who met the following requirements: - be over 18 years old; sign the free and informed consent form (FICF); be a meat products consumer. During taster's selection, were also considered non-smokers, with no respiratory diseases or olfactory syndromes.

3) Sensory Analysis Performance

The sensory evaluation was performed at the Laboratory of Dietary Technique and Gastronomy-USJT in individual booths. The entire experiment was conducted according to the Good Manufacturing Practices standards [18].

The different samples, after heating in plate to the internal temperature of $75^{\circ} \mathrm{C}$, were cut into four pieces. Color, taste and odor were the evaluated parameters by 40 untrained tasters, previously recruited. For this purpose, it was used a structured nine-point hedonic scale, in which, the number 1 corresponded to "extremely displeased" and the number 9, "I liked it extremely", according to the chart model presented in Appendix (Sensory analysis form template), provided by Anzaldúa-Morales [22]. The samples, coded with three digits, were served in plastic cups. During the tasting, tasters received cream cracker cookies and drinking water to clean the palate. The samples were presented in monadic form.

\section{Results and Discussion}

\subsection{Results regarding the Physicochemical Characterization of the Studied Formulations}

The physic-chemical characterization of the different hamburgers formulations after oven heat treatment are presented in Table 3.

Different samples moisture contents ranged from $51.20 \%$ to $61.57 \%$. This maximum variation of $10 \%$ among formulations may have occurred due to differences in the raw material itself, although it was from a single supplier. The heat inhomogeneity distribution in the furnace may have also contributed to the differences in the samples moisture content.

Table 3. Moisture/ash contents mean values and lipid percentage of the different hamburger formulations after baking.

\begin{tabular}{ccccccc}
\hline & \multicolumn{5}{c}{ Physicochemical composition (\%) } \\
\cline { 2 - 7 } Formulations & $\begin{array}{c}\text { Moisture content } \\
\text { determination }\end{array}$ & $\begin{array}{c}\text { Standard devia- } \\
\text { tion }\end{array}$ & $\begin{array}{c}\text { Ashes content } \\
\text { determination }\end{array}$ & $\begin{array}{c}\text { Standard } \\
\text { deviation }\end{array}$ & $\begin{array}{c}\text { Determination of } \\
\text { lipids }\end{array}$ & $\begin{array}{c}\text { Standard devia- } \\
\text { tion }\end{array}$ \\
\hline CF & 51.20 & 0.0006 & 3.73 & 0.0314 & 14.79 & 0.4382 \\
F1 & 55.58 & 0.0017 & 3.31 & 0.0286 & 12.90 & 14.13 \\
F2 & 58.73 & 0.0011 & 3.15 & 0.0212 & 11.08 & 0.1947 \\
F3 & 61.57 & 0.0019 & 3.42 & 0.0437 & 0.1031 \\
F4 & 57.48 & 0.0040 & 3.29 & 0.118 & 12.82 & 0.2446 \\
\hline
\end{tabular}


Meat in nature presents, on average, up to $0.9 \%$ of mineral or ash [23]. Ash contents above $1 \%$ found in hamburger samples are probably due to the addition of mechanically separated meat (MSM) to all formulations. While obtaining MSM, fragments of bird bones are incorporated into the meat, raising this ingredient ash contents.

Different formulations lipid content ranged from $11.08 \%$ to $14.79 \%$. The ingredients that contributed to these lipids amounts were bacon, mechanically separated meat and the chuck meat itself.

The mean values of thiobarbituric acid (TBA) reactive substances (TBARS), expressed as $\mathrm{mg}$ malonaldehyde/kg per sample, for the five baked hamburgers formulations stored at $-18^{\circ} \mathrm{C}$, for zero, 15 and 30 days are presented in Table 4.

Lipid oxidation extent in the different formulations over the storage at $-18^{\circ} \mathrm{C}$ is shown in Figure 1.

Table 4. Mean values of malonaldehyde concentration $/ \mathrm{kg}$ of sample for the different hamburger formulations.

\begin{tabular}{ccccccc}
\hline & \multicolumn{5}{c}{ mg malonaldehyde/kg of sample } \\
\cline { 2 - 7 } Formulations & 0 day & $\begin{array}{c}\text { Standard } \\
\text { deviation }\end{array}$ & 15 days & $\begin{array}{c}\text { Standard } \\
\text { deviation }\end{array}$ & 30 days & $\begin{array}{c}\text { Standard } \\
\text { deviation }\end{array}$ \\
\hline CF & 3.76 & 0.75 & 5.51 & 0.29 & 5.04 & 1.36 \\
F1 & 1.43 & 0.15 & 1.7 & 0.24 & 1.72 & 0.24 \\
F2 & 0.39 & 0.02 & 1.07 & 0.04 & 1.24 & 0.02 \\
F3 & 1.57 & 0.05 & 4.69 & 0.06 & 4.48 & 0.01 \\
F4 & 0.36 & 0.08 & 0.83 & 0.05 & 1.04 & 0.10 \\
\hline
\end{tabular}

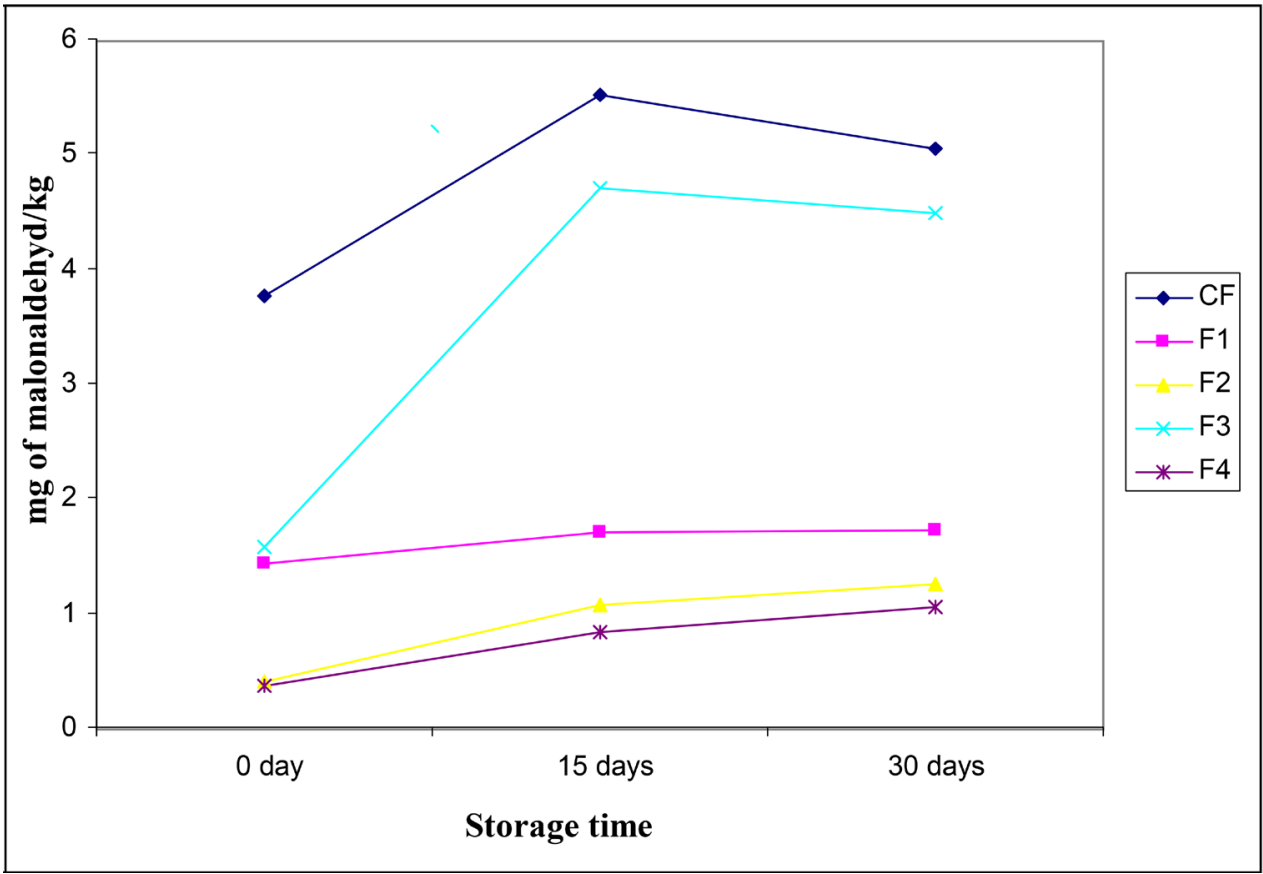

Figure 1. Extension of lipid oxidation of baked hamburger samples and stored at $-18^{\circ} \mathrm{C}$ up to 30 days. 
It is concluded from Table 4 and Figure 1 that the formulations F1 (sodium erythorbate), F2 (rosemary extract) and F4 (rosemary extract associated with oregano extract) presented the lowest concentrations of malonaldehyde, which means, greater stability during the storage period under freezing. The control formulation $(\mathrm{CF})$ showed higher values of TBA at time zero, indicating the product oxidation due to the absence of antioxidants. This oxidation increased during storage at $-18^{\circ} \mathrm{C}$.

The formulation containing only oregano extract (F3) had low values of TBA at time zero, but after fifteen days of storage under freezing, it had an increase in TBA values, suggesting that oregano extract did not perform as an antioxidant in the studied concentration.

In a study conducted by Tarcitano \& Mesquita [24], the Food Security of food was evaluated to guarantee the population physical and economic access to innocuous and nutritious products. This research aimed to investigate the occurrence of antimicrobial in the in natura food condiments used in the processing, preparation and/or consumption of fish, through a systematic review of the literature and covers articles published until July 2016. The authors concluded that the use of spices is a good combating the growth of bacteria, yeasts, filamentous fungi and synthesis of toxins as well as inhibiting or retarding the oxidation of fish. Similarly, oregano, rosemary and sage were the most effective antimicrobial condiments.

The results obtained in relation to the addition of rosemary extract coincide with those obtained by Pereira \& Pinheiro [25] although these authors used the ethanolic extract. In the study, these authors evaluated the inhibition of the hamburgers lipid oxidation and they found that the rosemary ethanolic extract inhibited the lipid oxidation in 21 days with a low production of malonaldehyde and with values very similar to the synthetic antioxidant (BHT) and they suggested this antioxidant substitution by rosemary extract.

\subsection{Results Related to Evaluated Organoleptic Characteristics: Color, Odor and Taste}

The mean values of the scores attributed by the tasters to the color, odor and flavor of the different samples baked and stored at $-18^{\circ} \mathrm{C}$ for 0,15 and 30 days are presented in Figures 2-4, respectively

According to Figure 2, at time 0, all samples had scores between 6 (slightly liked) and 7 (moderately liked) for color, thus having a good acceptance by the tasters. On the $15^{\text {th }}$ day, samples CF and F1 had scores between 5 (neither liked nor disliked) and 6 (slightly liked), while samples F2, F3 and F4 had a grade 6. At the end of storage, samples F3 and F4 received notes between 6 and 7 for this attribute.

Figure 3 shows that the control formulation (CF) received the lowest score for the odor attribute, that is, 6 , but this was not very different from the average of the other samples, which had a score close to 7 . After fifteen days of storage, the only sample that received mean between 6 and 7 was the F4. 
Mean values comparison for the color attribute

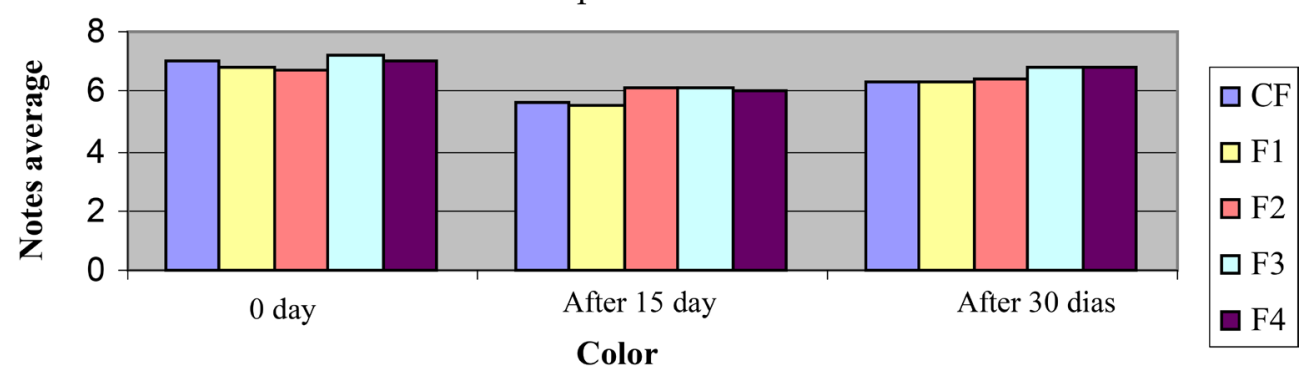

Figure 2. Mean values for the color attribute of the different hamburger samples when stored at $-18^{\circ} \mathrm{C}$ for 0,15 and 30 days ( $\mathrm{n}=40$ testers).

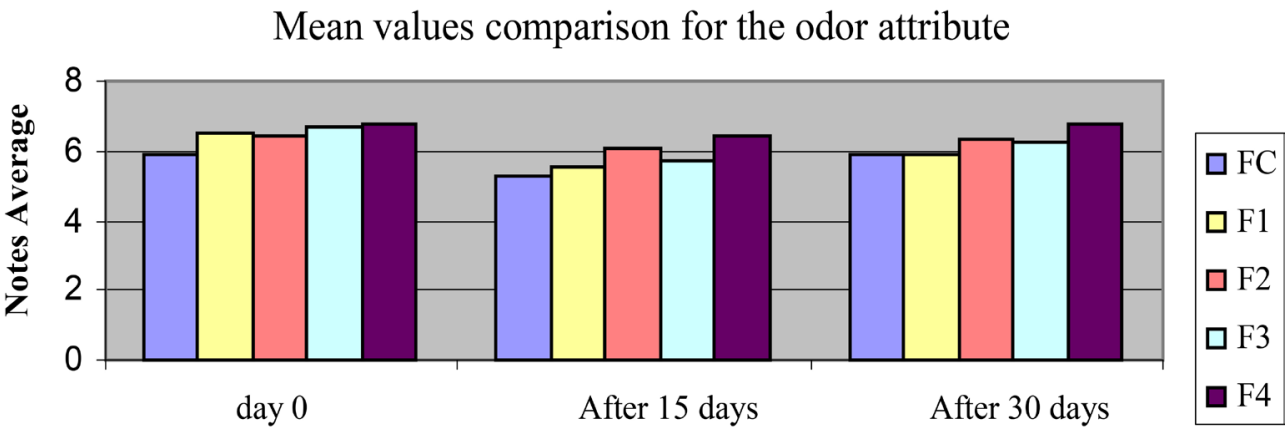

Odor

Figure 3. Mean values for the odor attribute of the different hamburger samples stored at $-18^{\circ} \mathrm{C}$ for 0,15 and 30 days ( $\mathrm{n}=40$ testers).

Mean values comparison for the flavor attribute

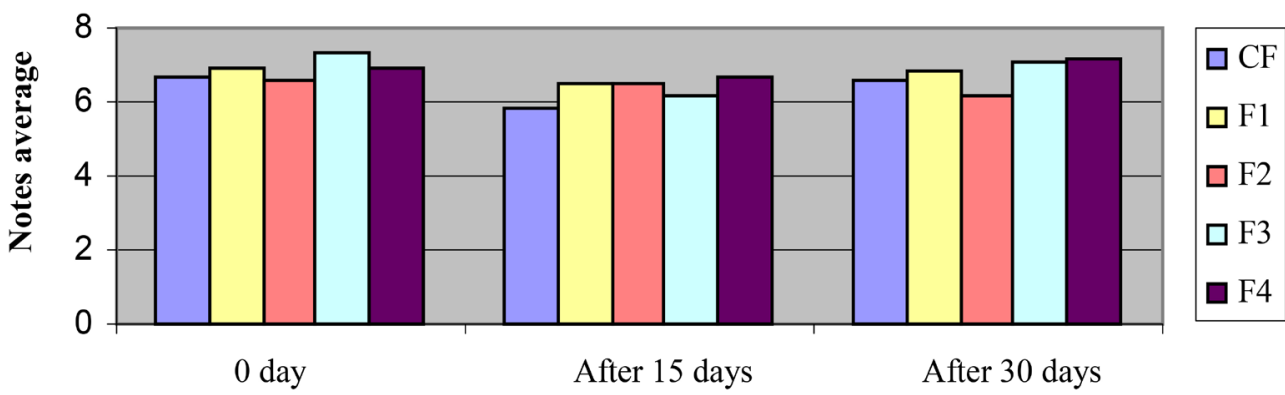

Flavor

Figure 4. Mean values for flavor attribute of different hamburger samples stored at $-18^{\circ} \mathrm{C}$ for 0,15 and 30 days $(\mathrm{n}=40$ testers).

However, no sample was classified below five for the odor attribute. After 30 days, all samples had an average of 6 or slightly higher.

Regarding the flavor attribute, all the samples were well accepted by the tasters during their storage, since the averages for this attribute varied between 5.8 and 7.3. It can be inferred that there was a preference for samples F3 (with oregano extract) and F4 (with extracts of rosemary and oregano).

Although the F3 sample presented an increase in oxidation during storage, a fact proven in TBARS determination, it received satisfactory averages for the 
attributes of color, odor and flavor, demonstrating that the lipid oxidation was not perceived by the evaluators during the studied period.

\section{Conclusion}

The study reveals that formulations F1 (with sodium erythorbate), F2 (with rosemary extract) and F4 (with rosemary and oregano extracts) showed good stability during the freezing period. The formulation containing only oregano extract did not have good stability during storage under freezing. However, reports from the sensory analysis from the tasters did not allow the establishment of a correlation between the scores attributed to color, odor and flavor and the said chemical changes.

\section{References}

[1] Garcia, C.E.R., Youssef, E.Y., Olivo, R. and Shimokomaki, M. (2002) Antioxidantes utilizados na indústria cárnea: Quais são os aditivos inibidores da rancidez nos produtos cárneos. (Antioxidants Used in Meat Industry: What Are the Additives That Inhibit Rancidity in Meat Products?). Revista Nacional da Carne, 26, 36-51.

[2] Silva, R.S., Silva, L.P., Lima, A.S., Oliveria, F.L.N. and Oliveira, G.A.A. (2014) Ação antimicrobiana dos óleos de orégano e alecrim em combinação ao nitrito frente à Staphylococcus coagulase positivo. Proceedings of the XII Latin American Congress on Food Microbiology and Hygiene (Blucher Food Science Proceedings), 1, 49-50. https://doi.org/10.5151/foodsci-microal-291

[3] Ramalho, V.C. and Jorge, N. (2006) Antioxidantes utilizados em óleos, gorduras e alimentos gordurosos. Química Nova, 29, 755-760.

https://doi.org/10.1590/S0100-40422006000400023

[4] Moreira, C.V.S. (2016) Hambúrguer de peixe voador (Hirundichthts affinis): Influência do alecrim (Rosmarinus officinalis) no perfil sensorial e características físicoquímicas. Dissertation (Master in Nutrition)-Centro de Ciências da Saúde, Universidade Federal do Rio Grande do Norte, Natal.

[5] Trindade, R.A. (2007) Influência de antioxidantes naturais sobre o perfil lipídico de hambúrgueres bovinos submetidos à irradiação por ${ }^{60} \mathrm{Co}$ e aceleradores de elétrons. (Influence of Natural Antioxidants on the Lipid Profile of Bovine Hamburgers Subjected to ${ }^{60} \mathrm{Co}$ Irradiation and Electron Accelerators). Instituto de Pesquisas Energéticas e Nucleares (IPEN). 03/2007.

[6] Gandra, E.A., Nogueira, M.B., Chim, J.F., Machado, M.R.G., Rodrigues R., Zambiazi, R.C., Voloski, F.L.S., Schneid, I. and Freitas, P.F. (2013) Antimicrobial and Antioxidant Potential of Extracts of Rosemary, Fennel, Tarragon and Orégano. Revista de Ciencia y Tecnología, 15, 24-29.

[7] Manhani, M.R. (2006) Estabilidade de cortes de lagarto bovino (M. semitendinosus) injetados e assados contendo diferentes sais de sódio e extrato de alecrim. (Stability of Injected and Roasted Bovine Meat (M. semitendinosus) Sections Containing Different Sodium Salts and Rosemary Extract). Thesis (Doctorate Degree). Faculdade de Engenharia de Alimentos Unicamp, Universidade Estadual de Campinas, Campinas.

[8] Genena, A.K., Hense, H., Smânia, A.J. and Souza, S.M. (2008) Rosemary-A Study of the Composition, Antioxidant and Antimicrobial Activities of Extracts Obtained with Supercritical Carbon Dioxide. Ciência e Tecnologia de Alimentos, Campinas, 28, 463-469. https://doi.org/10.1590/S0101-20612008000200030 
[9] Gray, J.I. (1978) Measurement of Lipid Oxidation. A Review. Journal of American Oil Chemistry, 55, 539-546. https://doi.org/10.1007/BF02668066

[10] Moreira, M.R., Ponce, A.G., del Valle, C.E. and Roura, S.I. (2005) Inhibitory Parameters of Essential Oils to Reduce a Foodborne Pathogen. LWT-Food Science and Technology, 38, 565-570. https://doi.org/10.1016/j.lwt.2004.07.012

[11] Chaul, L.T. (2015) Caracterização e determinação da atividade antimicrobiana dos extratos brutos e frações de Rosmarinus officinalis Linn. (alecrim), Origanum vulgare Linn. (orégano) e Capsicum chinense Jacq. (pimenta habanero). Dissertation (MSc in Pharmaceutical Sciences), Universidade Federal de Goiás, Goiânia.

[12] Peng, Y., Yuan, J., Liu, F. and Ye, J. (2005) Determination of Active Components in Rosemary by Capillary Electrophoresis with Electrochemical Detection. Journal of Pharmaceutical and Biomedical Analysis, 39, 431-437.

https://doi.org/10.1016/j.jpba.2005.03.033

[13] Frankel, E.N., Huang, S.W., Aeschbach, R. and Prior, E. (1996) Antioxidant Activity of a Rosemary Extract and Its Constituents, Carnosic Acid, Carnosol, and Rosmarinic Acid, in Bulk Oil and Oil-in-Water Emulsion. Journal of Agricultural and Food Chemistry, 44, 131-135. https://doi.org/10.1021/jf950374p

[14] Machado, B.A.S., Ribeiro, D.S. and Druzian, J.I. (2013) Estudo prospectivo relativo à atividade microbiana de algumas plantas aromáticas. Cadernos de Prospecção, 6, 97-105. https://doi.org/10.9771/S.CPROSP.2013.006.012

[15] Kikuzani, H. and Nakatani, N. (1989) Structure of a New Antioxidative Phenolic Acid from Oregano (Origanum vulgare L.). Agricultural and Biological Chemistry, 53, 519-524.

[16] Vekiari, S.A., Tzia, C., Oreopoulo, V. and Thomopoulos, C.D. (1993) Isolation of Natural Antioxidants from Oregano. Rivista Italiana delle Sostanze Grasse, 70, 25-28.

[17] Radaelli, M., Silva, B.P., Weidlich, L., Hoehne, L., Flach, A., Costa, L.A.M.A. and Ethur, E.M. (2016) Antimicrobial Activities of Six Essential Oils Commonly Used as Condiments in Brazil against Clostridium perfringens. Brazilian Journal of Microbiology, 47, 2. https://doi.org/10.1016/j.bjm.2015.10.001

[18] Brasil. Portaria SVS/MS n. 326, de 30 de julho de 1997 (1997) Technical Regulation on Hygienic-Sanitary Conditions and Good Manufacturing Practices for Establishments Producing and Industrializing Food.

http://portal.anvisa.gov.br/documents/33916/388704/Portaria\%2BSVS-MS\%2BN.\% 2B326\%2Bde\%2B30\%2Bde\%2BJulho\%2Bde\%2B1997.pdf/87alab03-0650-4e67-9f31 -59d8be3de167

[19] Brasil. Portaria Ministério da Saúde n. 1004, de 11 de dezembro de 1998 (1998) Approves the Technical Regulation: Assignment of Function of Additives, Additives and Their Maximum Limits of Use for Category 8-Meat and Meat Products. https://pt.scribd.com/document/49807410/Portaria1004-98-ANVISA-Aditivos-emCarnes

[20] Instituto Adolfo Lutz (São Paulo) (2008) Physicochemical Methods for Food Analysis. 4th Edition, Instituto Adolfo Lutz, São Paulo.

[21] Tarladgis, B.G., Watts, B.M., Younathan, M.T. and Dugan Jr., L. (1960) A Distillation Method for the Quantitative Determination of Malonaldehyde in Rancid Foods. The Journal of the American Oil Chemists Society, 37, 44-48. https://doi.org/10.1007/BF02630824

[22] Anzaldúa-Moralez, A. (1994) La evaluación sensorial de los alimentos em la teoría y la práctica. Acribia, Zaragoza.

[23] Universidade Estadual de Campinas-UNICAMP. Núcleo de Estudos e Pesquisas 
em Alimentação-NEPA (2006) Brazilian Table of Food Composition. 2nd Edition, NEPA-UNICAMP, Campinas.

http://www.crn1.org.br/wp-content/uploads/2015/04/taco.pdf?x53725

[24] Tarcitano, L.A.C. and Mesquita, E.F.M. (2017) In Natural Action of Spices in Food on Pathogenic Microbiota during Processing, Preparation and/or Consumption of Fish: A Systematic Literature Review. Arquivos de Ciências do Mar, Fortaleza, 50, 141-162.

[25] Pereira, D. and Pinheiro, R.S. (2013) Elaboration of Burgers with Natural Antioxidants from Ethanolic Extracts of Rosemary Rosmarinus officinalis L. Trabalho de Conclusão de Curso (Graduação)—Universidade Tecnológica Federal do Paraná, Pato Branco.

\section{Appendix: Sensory Analysis form Template}

\section{SENSORY ANALYSIS OF BOVINE MEAT HAMBURGER}

Name: Age:

E-mail:

Please sample Hamburger sample to evaluate how much you liked or disliked the sample, according to the scale.

9. I liked it very much

8 . I really liked it

6. I liked it 7. I liked moderately

slightly

5. Neither liked nor disliked

4. I slightly disagree

3. I disliked moderately

2. I did not like it very much.

1. Extremely disliked

Attributes Note

Color

Odor(smell)

Flavor

Comments: 